Jadranka Đurović Todorović ${ }^{1}$

P. $1-12$

Marina Đorđević ${ }^{2}$

University of Niš, Faculty of Economics

Milica Ristić Cakić3

University of Nišs, Innovation Center
ORIGINAL SCIENTIFIC PAPER

DOI: $10.5937 / E S D 2101001 D$

Received: September 5, 2020

Accepted: October 12, 2020

\title{
PENSION EXPENDITURE ANALYSIS: EMPIRICAL STUDY OF A SERBIAN LOCAL SELF-GOVERNMENT
}

\begin{abstract}
The problem of pension financing in the system of mandatory pension insurance in the Republic of Serbia became actual after the great economic crisis of the 1990s, although this problem had been present before. Accordingly, considerable attention has been paid to the analysis of determinants of pension expenditures. Considering the fact that in the Republic of Serbia the possibilities for reducing expenditures in the system of mandatory state pension and disability insurance have already been exhausted by reforms so far, it is necessary to consider other measures and possibilities for changing the design of the pension disability system. Therefore, the subject of this paper is the analysis of the relationship between pension beneficiaries, the type and amount of pensions. The aim of the paper is to analyze the influence of the pension beneficiary and the type of pension on the amount of the pension, based on the analysis of the collected data.
\end{abstract}

Key words: pension system, pension expenditure, pension beneficiaries, type of pension, Serbia.

JEL classification: H55, J26, H75

\section{АНАЛИЗА РАСХОДА ЗА ПЕНЗИЈЕ: ЕМПИРИЈСКО ИСТРАЖИВАЊЕ ЛОКАЛНЕ САМОУПРАВЕ У РЕПУБЛИЦИ СРБИЈИ}

\footnotetext{
Апстракт

Проблем финансирања пензија у систему обавезног пензијског осигурања у Републици Србији је постао актуелан након велике економске кризе 90-их година ХХ века, иако је присутност овог проблема била заступљена и раније. Анализи детерминанти расхода за пензије се, у складу са тим, почела поклањати велика пажна. Сходно томе да су у Републичи Србији могућности за смањење расхода у систему обавезног држсавног пензијског и инвалидског осигурања, досадашьим реформама већ исирпьене, неопходно је сагледати и друге мере и могућности за промену дизајна пензијско инвалидског система. Стога је предмет овог

1 jadrankadjt@gmail.com, ORCID ID 0000-0002-8910-2067

2 marina.djordjevic@eknfak.ni.ac.rs, ORCID ID 0000-0002-9909-315X

${ }^{3}$ milica42777@gmail.com, ORCID ID 0000-0003-3665-2361
} 
рада анализа односа између корисника пензије, врсте пензије и висине пензије. Циь рада је, да се на основу анализе прикупьених података, анализира утииај корисника пензије и врсте пензије на висину пензије.

Кьучне речи: пензијски систем, расходи за пензије, категорија корисника пензије, врста пензије, Србија.

\section{Introduction}

In the economic literature which examines the causes of crises of state pension systems, most attention has been paid to the disturbed relationship between the number of employees and the number of pensioners. This imbalance has had a major impact on the sustainability of the ongoing pension systems. However, significant repercussions on the frequent reforms of the pension systems in the world were also caused by shortcomings in the conduct of the pension policy, as well as the problem of social sustainability.

An estimate of the actuarial deficit as the difference between pension expenditures and contribution income indicates that the financial sustainability of most EU Member States is in jeopardy, given that contributions and other income over the 50-75-year period are insufficient to pay the projected retirement benefits during this period (D'Addio \& Whitehouse, 2012). One of the problems that is also highlighted in economic literature is the problem of social sustainability, which is a much broader concept than the previously mentioned problem of financial sustainability. Social sustainability is an actual problem that is interpreted as the adequacy of the pension, i.e. the relationship between the amount of the pension and the amount of earnings the insured person receives before the retirement status. In order to construct sustainable pension systems, factors that affect both financial and social sustainability must be considered. It is therefore important to consider pension policy effects that affect both sustainability when reforming the pension system. It is necessary to find a link between the two goals and strive for their balance. In order to achieve this, a detailed analysis of the pension income and expenditure is necessary.

The provision of pensions in the mandatory pension system faces major problems in the world, with the increasing number of pensioners relative to the number of employees as the main factor. Explicitly, one of the causes of the deficit in pension payments is the reduction in the pension system's income and the increase in pension expenditures. The increase in pension expenditures emphasizes the increase in the number of pensioners, but also the reforms of the conditions for retirement, which are becoming more and more liberal. According to the projected pension expenditures for the period up to 2050 in most EU countries, the amount of pension contributions will not be sufficient to finance them (European Commission, 2009). Pension expenditures in Serbia represent the most important category of expenditures of the Republic Pension and Disability Insurance Fund, bearing in mind that they account for about $85 \%$ of the total expenditures of the Fund.

However, the pension system of the Republic of Serbia is unsustainable in the long run, which is the reason for many authors' interest in reforming this system (ĐurovićTodorović \& Đorđević, 2018). Considering the problems of financing pensions and finding the ways for the sustainable functioning of the pension system in the Republic of Serbia, we conducted a detailed analysis of the structure of pension expenditures. The paper analyzes 
the relationship of the pension beneficiary, the type of pension and the amount of pensions. In order to examine the sustainability of the pension system in the Republic of Serbia, the aim of the paper is to examine whether the category of pension beneficiaries and the type of pensions have an impact on the amount of pensions. The data collected for the empirical analysis were provided by the Republic Pension and Disability Insurance Fund - Leskovac Branch and relate to the structure of expenditures for pensions at the city level. Considering that the possibilities for reducing expenditures in the system of mandatory state pension and disability insurance for some types of pensions have already been exhausted, it is necessary to consider other measures and possibilities for changing the design of the Serbian pension disability system. Starting from the fact that the unsustainability of state pension systems is a consequence of the inconsistency of pension system design with the changes that occur in the contemporary environment, the results of the survey indicate a complete picture of the structure and scope of expenditures for pensions at a local level and possible directions for the reform of the pension insurance system in Serbia.

\section{Determinants of the crises in a pension system}

The crisis in pension systems is present in all countries of the world. It is evident in the European Union countries that the design of the pension system differs significantly between the Member States and that generating differences between them leads to different sustainability.

The main factors affecting the crisis in the functioning of the pension insurance system and the economic security of pension beneficiaries are longer life expectancy of the population than expected, global economic crises, high unemployment rates, globalization, competitiveness in the field of pension insurance as well as the forms of pension benefits payment. According to Rakonjac-Antic (2013), for a pension system to work, all forms of payment of pension benefits need to be anticipated in advance. Determination of pension benefits also plays a major role in pension system functioning. "Depending on whether the pre-defined formula, with parameters, for determining the pension benefit, or the pension benefit depends on the amount of the accumulated contribution funds and the return on the invested contribution funds, there is a division into: defined benefit plans, defined benefit plans contributions and hybrid plans" (Rakonjac Antić, 2013, p. 128).

According to Holzmann et al. (2003), the crisis of pension systems is influenced by the link between pension benefits and contributions, which needs to be strengthened, but also by the factors related to sources of pension financing such as the contribution period and sources of pension financing. According to this author, it is very important to introduce changes in the pension structure.

Matkovic (2010) analyzes the impact of the number of pension beneficiaries on the amount of net pension expenditure. The author considers that the decrease in income is a consequence of the decrease in the number of insured persons due to the decrease in the number of employees, the avoidance of contributions and the informal economy, and the increase in expenditures is the consequence of the increase in the number of pension beneficiaries due to the aging of the population and liberal retirement conditions (Matković, 2005).

The complexity of the pension system functioning is recognized by international and national statistical institutions as well as by research institutions. According to Stanc et al. 
(2019), the pension system is influenced by demographic policy, intergenerational relations, general equilibrium in the country, public debt, but also by macroeconomic balance. "Aging, falling employment rates, financial market volatility, pose serious problems for the sustainability of the pension system" (Stanc et al., 2019, p. 53). According to Stanc et al., (2019) any study on the sustainability of retirement and disability insurance begins with at least three demographic problems that a state faces or will face over the next 40 years: population decline, population aging, and emigration. All these factors call into question the sustainability of pension systems. Dobre et al. (2012) consider that every state must maintain its public debt at a reasonable level in order to cope with public spending increases in the future due to demographic trends. Peter Askins (2010) analyzes the challenges facing pension policy makers regarding sustainability and risk, emphasizing the need for change in Europe with aging population and declining birth rates.

Barr et al. (2009) indicate that there are a number of pension design principles that are rooted in the economic theory. Some of these principles are: pension systems have multiple goals, their analysis should consider the pension system as a whole, different systems face different risks, different systems have different effects by generation and gender. The emanation of this discussion is increasing with the emergence of errors in the World Bank's work and the emergence of irregular analyzes of pension debt and incomplete analyzes of pension systems. In his research, the author emphasizes the necessity of a complete analysis of pension systems that differ depending on the level of economic development of different countries.

Some research points to the importance of the moment of retirement, and they find a solution to the pension system crisis in examining the optimum time for retirement. In order to define retirement age, it is necessary to start from what defines retirement. However, there is still no consensus on the definition of retirement in literature (Gustman, Mitchell $\&$ Steinmeier, 1995). Montalto et al. (2000) analyze the determinants of the retirement age limit. Their research findings highlight that retirement adequacy research should focus on planned retirement. Financial planners should consider that the planned retirement of all categories of beneficiaries increases with age. Accordingly, his study focuses on the financial characteristics of the pension as well as on the demographic characteristics of the pension as one of the determinants of the retirement limit. Boskin (1977) indicates that the level of net earnings can have a strong negative impact on the likelihood of retirement. Stojilković (2011) uses indicators such as years of service and average retirement age into retirement structures in Serbia. The author considers that the average retirement age is of great importance for the financial sustainability of the Pension and Disability Insurance Fund. Due to the fact that retirement life expectancy is increasing, longer use of the pension is expected. "The data of the Pension and Disability Insurance Fund show tendencies that will continue in the future, as all processes related to the population are long-term, including those related to pensioners who are, in addition to socio-economic factors, influenced by demographic factors" (Stojilković, 2011, p. 69).

As in most other countries, pension and disability insurance in Serbia is based in part on the ongoing pension financing. Mandatory insurance covers: employees, employers, the self-employed and farmers. At the end of 2000, large debts in the pension and disability system were found in Serbia. Difficulties in financing pensions in Serbia were around since the mid-1980s to cumulate during the 1990s, which was compounded by workforce reduction, avoidance of contributions and a decrease in the number of insured persons. On 
the other hand, due to the existence of liberal conditions of retirement and the aging of the population, there was a constant growth in the number of pensioners. According to Matkovic (2001), pension financing required increasingly "creative" measures.

"The uncertainties regarding the causes of the growing deficit in the pension system of the Republic of Serbia make its difficult situation even worse" (Bajec \& Stanic, 2005, p. 52). The authors Bajec \& Stanic (2005) explain that the problems that the pension system in Serbia has fallen into are, in fact, a consequence of the economic crisis of the late 1990s, but also of the inefficient management of the pension policy. In their study, the authors analyze the factors that influence the dynamics of the pension system deficit and conclude that pension financing system should not be viewed partially but as an integral part of social security and public expenditures.

In the Republic of Serbia, pensions are part of the expenditures of the mandatory pension and disability insurance system. However, pension expenditures represent the most significant category of expenditures of the Republic Pension and Disability Insurance Fund in our country. These expenditures include expenditures for old-age, invalidity and survivor pensions, which are paid to pension beneficiaries such as employees, farmers, military insurers and pension beneficiaries in the self-employed category. According to statistics, pension expenditures record an upward trend resulting from the increase in the number of pension beneficiaries and the average value of the pension. In order to analyze the structure of expenditures of the mandatory pension and disability insurance system, the following section analyzes the categories of insured persons and types of pensions at the local level in the Republic of Serbia.

\section{Data and Methodology}

Since 2012 in the Republic of Serbia pension expenditures have included the pensions of employees, self-employed, farmers and professional military personnel. For the sake of the accuracy of the analysis of pension expenditures by population categories, the data were collected at the city level.

The hypothesis was analyzed using primary data obtained from the Republic Pension and Disability Insurance Fund and the Republic Pension and Disability Insurance Fund Leskovac Branch. Also, the problem was analyzed using the secondary data published in the statistical monthly bulletin of the Republic Pension and Disability Insurance Fund, as well as on the basis of the statistics of the Republic Bureau of Statistics.

Based on the quantitative data on the number of beneficiaries of the Pension and Disability Insurance Fund in Leskovac and their disbursements, we have analyzed the pension beneficiaries in the following categories: a) 24,427 pension beneficiaries from the category of employees; b) 4,781 pension beneficiaries from the farmer category; c) 1,666 pension beneficiaries from the self-employed category; d) 415 pension beneficiaries from the military insurance category.

The main objective of the research was to determine whether the category of pension beneficiary influences the amount of the pension paid to him, as well as to examine whether the type of pension influences the amount of the paid pensions in Leskovac. We used Twoway between - groups analysis of variance which implicitly allowed us to explore the joint impact of two independent variables, on one dependent variable. 
We used the data provided from the Republic Pension and Disability Insurance FundBranch Office Leskovac on pension beneficiaries in November 2019, by pension groups (Table 1).

Table 1: Groups of pension amounts

$$
\begin{aligned}
& 1-10000 \\
& 10000.01-15000 \\
& 15000.01-20000 \\
& 20000.01-25000 \\
& 25000.01-26643.75 \\
& 26643.76-27899.36 \\
& 27899.37-29250.77 \\
& 29250.78-30000 \\
& 30000.01-30709.45 \\
& 30709.46-32288.50 \\
& 32288.51-34003.90 \\
& 34003.91-35000.00 \\
& 35000.01-40000 \\
& 40000.01-45000 \\
& 45000.01-50000 \\
& 50000.01-55000 \\
& 55000.01-60000 \\
& 60000.01-70000 \\
& 70000.01-80000 \\
& 80000.01-90000 \\
& 90000.01-100000 \\
& 100000.01-999999.99
\end{aligned}
$$

Source: Statistical Monthly Bulletin H/2019: Number of pension beneficiaries and funds for the payment by the amount of pensions, Republic Pension and Disability Insurance Fund.

The advantage of the two-factor analysis of variance is in the fact that it examines the basic influence of both independent variables and the possible influence of their interaction. Using different statistical tools, we analyzed the interaction which occurs when the influence of one independent variable on a dependent variable changes and when that change is initiated depending on the value of another independent variable. The independent variables in the model are pension beneficiary category and type of pension, while the dependent variable, the amount of pensions for each pension beneficiary category was calculated using the following formula:

$$
\mathrm{PP}=\frac{T A P}{T N B}
$$

where, PP is the average amount of funds disbursed by groups of pension amounts and type of pension or the average amount of pensions paid out by each group of pension amount and type, TAP is the total amount of pensions paid to beneficiaries of a certain type of pension by 
groups of amounts of pensions, and TNB is the total number of beneficiaries of a certain type of pension by groups of amounts of pensions.

Table 2: Results of the analysis of variance for an independent variable-pension beneficiary category

\begin{tabular}{|l|r|r|r|r|r|}
\hline \multicolumn{1}{|c|}{ Dependent Variable: PP } & \multicolumn{1}{c|}{$\begin{array}{l}\text { Type III Sum of } \\
\text { Squares }\end{array}$} & \multicolumn{1}{c|}{ df } & \multicolumn{1}{c|}{ Mean Square } & \multicolumn{1}{c|}{ F } & \multicolumn{1}{c|}{ Sig. } \\
\hline Corrected Model & \multicolumn{1}{c|}{$7556060301.800^{\mathrm{a}}$} & 3 & 2518686767.267 & 5.326 & .002 \\
\hline Intercept & 175695792379.244 & 1 & 175695792379.244 & 371.531 & .000 \\
\hline $\begin{array}{l}\text { Pension beneficiary } \\
\text { category }\end{array}$ & 7556060301.800 & 3 & 2518686767.267 & $\mathbf{5 . 3 2 6}$ & $\mathbf{. 0 0 2}$ \\
\hline Error & 81811184948.252 & 173 & 472897022.822 & & \\
\hline Total & 330201662087.951 & 177 & & & \\
\hline Corrected Total & 89367245250.052 & 176 & & & \\
\hline
\end{tabular}

$\mathrm{R}$ Squared $=.085($ Adjusted R Squared $=.069)$

Source: Authors

Based on the results presented in Table 2, we can conclude that there is a significant difference between the mean values of the dependent variable in the four groups (employees, craftsmen, farmers, military). The overall significance is Sig $=0.002$, which is less than 0.005 , i.e. the result of one of the groups is statistically significant.

Table 3: Results of analysis of variance for an independent variable-type of pension

\begin{tabular}{|l|c|c|c|c|c|}
\hline \multicolumn{1}{|c|}{ Dependent Variable: ПП } & $\begin{array}{c}\text { Type III Sum of } \\
\text { Squares }\end{array}$ & df & Mean Square & F & Sig. \\
\hline Corrected Model & $2704058690.010^{\mathrm{a}}$ & 2 & 1352029345.005 & 2.715 & .069 \\
\hline Intercept & 237674265543.047 & 1 & 237674265543.047 & 477.196 & .000 \\
\hline Type of pension & 2704058690.010 & 2 & 1352029345.005 & 2.715 & .069 \\
\hline Error & 86663186560.042 & 174 & 498064290.575 & & \\
\hline Total & 330201662087.951 & 177 & & & \\
\hline Corrected Total & 89367245250.051 & 176 & & & \\
\hline
\end{tabular}

a. $\quad$ R Squared $=.030$ (Adjusted R Squared $=.019$ )

\section{Source: Authors}

Based on the results in Table 3, we conclude that there are no statistically significant differences between the mean values of the dependent variable in the three groups (disability, old-age and family pensions). The table below gives the average pension amounts by the category of the beneficiary and the type of pension. 
Table 4: Descriptive Statistics

\begin{tabular}{|c|c|c|c|c|}
\hline \multicolumn{5}{|c|}{ iable: ПП } \\
\hline \multicolumn{2}{|c|}{ Type of pension } & Mean & Std. Deviation & $\mathrm{N}$ \\
\hline \multirow[t]{5}{*}{ Invalidity } & Employees & 43637.8335 & 26635.06196 & 2 \\
\hline & Craftsmen & 33602.2745 & 17118.06127 & 17 \\
\hline & \begin{tabular}{|l} 
Agricultural workers \\
\end{tabular} & 16865.7046 & 9198.83879 & \\
\hline & Military & 39533.4879 & 15893.45607 & 16 \\
\hline & Total & 37468.9222 & 21390.61950 & 60 \\
\hline \multirow[t]{5}{*}{ Old-age } & Employees & 43584.6308 & 26581.51677 & 22 \\
\hline & \begin{tabular}{|l|} 
Craftsmen \\
\end{tabular} & 35585.2204 & 17426.69543 & 19 \\
\hline & \begin{tabular}{|l|l|c|} 
Agricultural workers \\
\end{tabular} & 27622.4826 & 12137.89970 & \\
\hline & Military & 60878.9760 & 41500.92026 & 10 \\
\hline & Total & 41090.6151 & 26827.48940 & 62 \\
\hline \multirow[t]{5}{*}{ Survivors } & Employees & 35475.6411 & 20375.92187 & 19 \\
\hline & Craftsmen & 29460.7536 & 12818.12185 & \\
\hline & 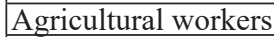 & 12212.0656 & 8924.11062 & \\
\hline & Military & 33437.5503 & 15487.25936 & 17 \\
\hline & Total & 31513.3655 & 17086.19952 & 5 \\
\hline \multirow[t]{5}{*}{ Total } & Employees & 41157.6412 & 24785.40657 & 0. \\
\hline & \begin{tabular}{|l|} 
Craftsmen \\
\end{tabular} & 33122.9247 & 15984.61536 & 5 \\
\hline & \begin{tabular}{|l|l|c|} 
Agricultural wors \\
\end{tabular} & 21851.2047 & 12382.05851 & 2( \\
\hline & Military & 42087.5331 & 25836.10475 & 43 \\
\hline & I lotal & 36886.9411 & 22533.71782 & 11 \\
\hline
\end{tabular}

Source: Authors

In the category of disability pension beneficiaries, employees have the highest average pension amount. In the category of old-age pension beneficiaries, the highest average pension amount is attributed to the members of the military, while the last observed category, family pension beneficiaries, has the highest average pension amount for employees. On the other hand, the disability pension beneficiary category recorded the lowest average pension amount for farmers, and the same result was observed for the other two pension beneficiary categories.

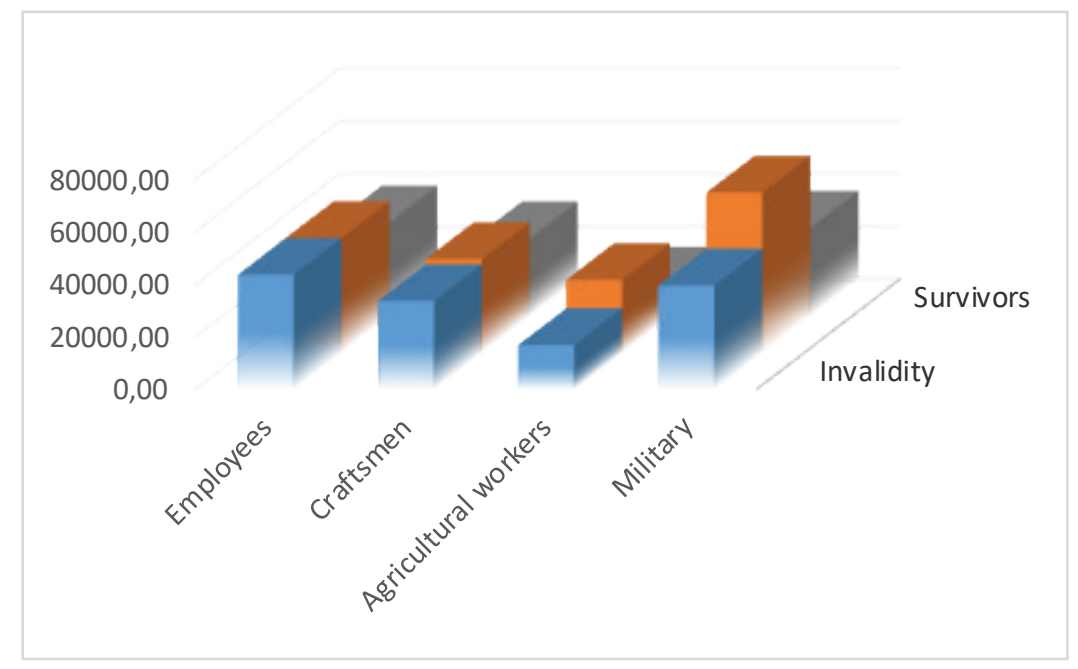

Figure 1: Descriptive statistics of the observed categories of pension beneficiaries Source: Authors 
To determine whether there is an influence of interaction (factors, independent variables) in the model on the observed dependent variable, we used the two-factor analysis of variance of different groups. The results of the two-factor analysis of variance are given in Table 5.

Table 5: The results of the two-factor analysis of variance

\begin{tabular}{|c|c|c|c|c|c|}
\hline \multicolumn{6}{|c|}{ Dependent Variable: PP } \\
\hline Source & $\begin{array}{c}\text { Type III Sum of } \\
\text { Squares }\end{array}$ & df & Mean Square & $\mathrm{F}$ & Sig. \\
\hline Corrected Model & $14524510637.266^{\mathrm{a}}$ & 11 & 1320410057.933 & 2.911 & .002 \\
\hline Intercept & 156526984900.651 & 1 & 156526984900.651 & 345.083 & .000 \\
\hline Type of pension & 4769670011.999 & 2 & 2384835006.000 & 5.258 & .006 \\
\hline $\begin{array}{l}\text { Pension } \\
\text { beneficiary } \\
\text { category }\end{array}$ & 9608028218.348 & 3 & 3202676072.783 & 7.061 & .000 \\
\hline $\begin{array}{l}\text { Type of pension } \\
* \text { beneficiary } \\
\text { category }\end{array}$ & 2628462808.325 & 6 & 438077134.721 & .966 & .450 \\
\hline Error & 74842734612.785 & 165 & 453592330.987 & & \\
\hline Total & 330201662087.951 & 177 & & & \\
\hline Corrected Total & 89367245250.052 & 176 & & & \\
\hline
\end{tabular}

Source: Authors

Based on the obtained results, it can be concluded that there are statistically significant differences in the average amounts of disbursed funds or the average amounts of pensions between different categories of pension beneficiaries ( $F=7.061$, Sig. 0.000). The highest pensions are paid to the members of the military and employees, slightly lower pensions are paid to craftsmen, while the lowest pensions are paid to farmers. Also, significant differences in the amount of pensions exist between different types of pensions $(F=5.258$, Sig. $=$ 0.006). The highest pensions are old age, then disability and family. There was no interaction between the two independent variables $(F=0.966$, Sig. $=0.450)$. In the case of disability pensions, old-age and family pensions, employees and the members of the military have the highest pensions, craftsmen have slightly lower pensions, while farmers have the lowest pensions. Therefore, there is no difference between the two factors analyzed (type of pension and category of pension beneficiaries) in pension amounts. We conclude that the category of pension beneficiaries and the type of pension do not have a statistically significant effect on the amount of pensions in Leskovac.

\section{Conclusion}

The pension policy, which emphasized the problem of the pension system reform in the Republic of Serbia, was mainly focused on reconciling the disturbed relationship between the number of employees and the number of pensioners. The reconciliation of these variables is caused by an increase in the number of pensioners and a decrease in the number of employees in our country. Our analysis of the scope and structure of pension expenditures as the dominant and most important category of expenditures of the Pension and Disability Insurance Fund 
of the Republic of Serbia has shown a complete picture of expenditures arising from the payment of pensions in order to thoroughly review and examine the determinants of the sustainability of pension systems.

The financial and social sustainability of the pension system, as outlined in the introductory part of the paper, must be based on a complete analysis of expenditures. Bearing in mind the diversity of national pension systems, specific economic and social conditions, Serbia's pension policy reflects its responsibility both in terms of regulation and laws related to pension expenditures and as a function of a sustainable pension system. The Europe 2020 Strategy recommends reducing public debt, increasing employment and reforming the social security system. Mercer and the CFA Institute presents "ideal retirement systems" based on fundamental principles (Mercer \& CFA Institute, 2018): clear government targets for each pension pillar, the minimum level of funding for general retirement savings, effective pension schemes for both the retirement period and the post-retirement period, transparency of the administrative and investment costs of each retirement plan, flexibility, contributions or raising capital during the years of retirement, accumulated benefits, sustainable relief to encourage voluntary savings, corporate pension funds management that is independent from the government, the protection of participants in the pension system. In Serbia, in the medium term, funding for pensions and the sustainability of the pension and disability system can be obtained by increasing employment or by reducing the presence of the informal economy. However, in the long run, the problems that are inevitable, including the aging of the population, the extension of the retirement age, lead to the unsustainability of state pension systems based on ongoing pension funding.

The results of our study show that at the city level there are statistically significant differences in average amounts of disbursed funds or average amounts of pensions between different categories of pension beneficiaries ( $F=7.061$, Sig. 0.000). The highest pensions are paid to the members of the military and employees, slightly lower pensions are paid to craftsmen, while the lowest pensions are paid to farmers. Also, significant differences in the amount of pensions exist between different types of pensions $(\mathrm{F}=$ 5.258 , Sig. $=0.006$ ). The highest pensions are old age ones, followed by the ones of disability and survivors. The study results also showed that there was no interaction between the two independent variables $(\mathrm{F}=0.966$, Sig. $=0.450)$. Therefore, there is no difference between the two factors analyzed (type of pension and category of pension beneficiaries) in pension amounts, i.e., the category of pension beneficiaries and the type of pension do not have a statistically significant effect on the amount of pensions in Leskovac.

This paper examined the structure of city-level pension expenditures and it can provide a basis for further examination of the factors associated with expenditure reductions and improve the ability to analyze pension system policies, including proposed changes to the social security program. Also, the study can provide a better insight into the factors that should be included in the analysis when assessing the determinants of retirement. The survey tends to move pensions across all categories of retirees and points to problems that can cause an imbalance in the pension system. The paper also points to the necessity of further research at the national level. 


\section{References}

Anna Cristina, D. A., Whitehouse, E., \& Suisse. Office fédéral des assurances sociales. (2012). Towards financial sustainability of pension systems: The role of automatic-adjustment mechanisms in OECD and EU countries. Bundesamt für Sozialversicherungen.

Antic, T. R., \& Jovovic, M. (2014). Forms of Pension Benefit Payments. Eur. Ins. L. Rev., 9.

Askins, P. (2010). The future of pensions policy in Europe. Pensions: An International Journal, 15(4), 245-248.

Bajec, J., \& Stanić, K. (2005). Koliki je stvarno deficit penzionog sistema u Srbiji. Fren, Beograd: Kvartalni monitor ekonomskih trendova i politika u Srbiji, 52-58.

Barr, N., \& Diamond, P. (2009). Reforming pensions: Principles, analytical errors and policy directions. International social security review, 62(2), 5-29.

Boskin, M. J. (1977). Social security and retirement decisions. Economic inquiry, 15(1), $1-25$.

Dobre S., Ioniţă S. şi Marinache D. (2012), Carta albă a pensiilor - RO, Working paper no. 3, EFOR, 2012.

Đurović-Todorović, J., Đorđević, M. (2018). Pension systems sustainability in the Republic of Serbia, In: Konkurentnost i održivi razvoj privrede Republicke Srbije, Niš, Srbija: Ekonomski fakultet Univerziteta u Nišu, 139-157.

European Commission (2017). Romania, Country fiche on pension projections prepared for the Economic Policy. Committee, Available at: https:/europa.eu/.../romania_country_fiche_on_pensions.

European Commission (2018). 2018 Ageing Report: Economic and Budgetary Projections for the EU 27 Member States (2016-2060), Institutional paper 079 | may 2018.

European Commission. (2009). Portfolio of Indicators for the Monitoring of the European Strategy for Social Protection and Social Inclusion-2009 Update. Brussels: European Commission.

Foltin, C. (2018). An examination of state and local government pension underfundingImplications and guidance for governance and regulation. Research in Accounting Regulation, 30(2), 112-120.

Glaeser, E. L., \& Ponzetto, G. A. (2014). Shrouded costs of government: The political economy of state and local public pensions. Journal of Public Economics, 116, 89105.

Gustman, A. L., \& Steinmeier, T. L. (1999, June). Effects of pensions on savings: analysis with data from the health and retirement study. In Carnegie-Rochester conference series on public policy (Vol. 50, pp. 271-324). North-Holland.

Gustman, A. L., Mitchell, O. S., \& Steinmeier, T. L. (1995). Retirement measures in the health and retirement study. Journal of Human Resources, S57-S83.

Holzmann, R. (2013). Global pension systems and their reform: Worldwide drivers, trends and challenges. International Social Security Review, 66(2), 1-29. 
Martineau, J. N. (2004). The national pension system of Serbia: Preliminary fiscal analysis. USAID-Bearing Point.

Matković, G. (2001). Reforme socijalnog sektora. Strategija reformi. Belgrade: CLDS, 23-26.

Matković, G. (2005). Reforma penzijsko-invalidskog sistema. Četiri godine tranzicije u Srbiji CLDS, 329-337.

Matković, G. (2010). Najčešće zablude o penzijskom sistemu u Srbiji, In: Institucionalne reforme u 2009. Godini, Available at: http://csp.org.rs/en/assets/publications/files/ Goga-FOKUS.pdf

Montalto, C. P., Yuh, Y., \& Hanna, S. (2000). Determinants of planned retirement age. Financial Services Review, 9(1), 1-15.

Rakonjac-Antić, T. (2013). Management of key pension plan risks from the user aspects. Marketing, 44(2), 128-136.

Rakonjac-Antić, T. (2013). Management of key pension plan risks from the user aspects. Marketing, 44(2), 128-136.

Republički fond za penzijsko i invalidsko osiguranje (2019). Statistički mesečni bilten za decembar 2019. godine, Beograd.

Stancu, I., Haseganu, D., \& Darmaz-Guzun, A. (2019). Projections on the sustainability of the pension system in Romania (No. 0028). Institute of Financial Studies.

Stojilković, J. (2011). Growing number of pensioners and population aging in Serbia. In: Zbornik radova Geografskog instituta Jovan Cvijic, SANU, 61(2), 69-84.

Vella, M., \& von Brockdorff, P. (2019). Pensions across generations: scenarios for the Maltese Islands. Journal of International and Comparative Social Policy, 35(3), 280298. 